\title{
Efektivitas Pemberian Berbagai Dosis Pupuk Cair Urine Sapi terhadap Pertumbuhan dan Hasil Tanaman Buncis (Phaseolus vulgaris L.) pada Lahan Podsolik
}

\section{(The Effectiveness of Giving Cow Urine Liquid Fertilizer Various Dosage on The Growth and Yield Crop Beans (Phaseolus vulgaris L.) on Podsolic Land)}

\author{
Nur Hafizah ${ }^{1)}$ \& Syahran ${ }^{2}$ \\ Program Studi Agroteknologi, Sekolah Tinggi Ilmu Pertanian Amuntai \\ ${ }^{1)}$ Fifi_bjm@yahoo.co.id \\ ${ }^{2)}$ syahran@yahoo.com
}

\begin{abstract}
ABSTRAK
Buncis (Phaseolus vulgaris L.) sarat dengan vitamin $A, B$ dan $C$ dan sumber penting sayuran. Masalah yang dihadapi dalam pengembangan pertanian tanaman pada lahan podsolik $p H$ sangat rendah dan miskin gizi. Tujuan Penelitian ini untuk (i) mengetahui pengaruh pemberian berbagai dosis pupuk urine sapi terhadap pertumbuhan dan hasil tanaman buncis pada lahan podsolik (ii) mendapatkan dosis terbaik dari berbagai macam dosis pupuk urnie sapi terhadap pertumbuhan dan hasil tanaman buncis pada lahan podsolik. Penelitian ini dilaksanakan di Desa Pantai Hambawang Timur Kecamatan Labuan Amas Selatan Kabupaten Hulu Sungai Tengah dari bulan Juni-Juli 2014, penelitian ini menggunakan Rancangan Acak Kelompok (RAK), dengan 5 perlakuan dan 4 ulangan, sehingga didapatkan 20 satuan percobaan, dan setiap perlakuan ada 4 tanaman. Faktor yang diuji adalah dosis pupuk cair urine sapi, yaitu : $t_{0}=0$ $c c . \ell^{-1}$ per petakan, $t_{1}=35 \mathrm{cc} . \ell^{-1}$ per petakan, $t_{2}=45 \mathrm{cc} . \ell^{-1}$ per petakan, $t_{3}=55 \mathrm{cc} . \ell^{-1}$ per petakan, $t_{4}=65 \mathrm{cc} . \ell^{-}$ ${ }^{1}$ per petakan. Hasil penelitian ini menunjukkan. Bahwa dosis perlakuan pupuk cair urin sapi secara signifikan mempengaruhi panjang tanaman 15, 25 dan 35 HST, jumlah polong dan berat polong tanaman pada dosis 65 cc. $\ell^{-1}\left(t_{4}\right)$. Perlakuan berbagai dosis pupuk urine sapi berpengaruh nyata terhadap semua peubah yang diamati, yaitu panjang tanaman, jumlah polong dan berat polong tanaman buncis pada lahan podsolik dengan dosis terbaik $65 \mathrm{cc} . \ell^{-1}$.
\end{abstract}

Kata kunci: Urin, sapi, cairan, pupuk, lahan, podsolik.

\section{ABSTRACT}

Beans (Phaseolus vulgaris L.) are loaded with vitamin A, B and Can important source of vegetable. Problems faced in the development of crop farming on the land podzolic very low $p H$ and nutrient poor. This study aims to (i) determine the effect of cow urine liquid fertilizer on the land podsolic on growt hand yield of beans, (ii) get adose of liquid fertilizer of cow urine is best for the growt hand yield of chick peain podzolic land. The research was conducted in Pantai Hambawang Timur Village Labuan Amas Selatan District Hulu Sungai Tengah Regency, June-July 2014, this study uses randomized block design (RBD), with 5 treatments and 4 replications, so we get 20 units of the experiment, and each treatment there 4 plants. The factors tested are liquid fertilizer of cow urine, namely: $t_{0}=0 \mathrm{cc} \cdot \ell^{-1}$ per map, $t_{1}=35 \mathrm{cc} . \ell^{-1}$ per map, $t_{2}=45 \mathrm{cc} . \ell^{-1}$ per map, $t_{3}=55 \mathrm{cc} . \ell^{-1}$ per map, $t_{4}=65 \mathrm{cc} . \ell_{-}{ }^{1}$ per map. The results of this study indicate. That treatment doses of liquid fertilizer of cow urine significantly affect thelength of the plant ages 15, 25 and 35 DAP, number of pods and pod weight of cropat a dose of $65 \mathrm{cc}$ perlite $r$ of water perplot $\left(t_{4}\right)$. So the bean plants can be grown on land podzolic when treated with optimal doses of liquid fertilizer of cow urine according to his research, by using a dose of $65 \mathrm{cc} . \ell^{-1}$ per map.

Keywords: Urine, cow, liquid fertilizer, land, podsolic.

\section{PENDAHULUAN}

Buncis merupakan tanaman semusim yang berbentuk perdu yang sangat digemari oleh masyarakat karena rasanya enak dan gurih, serta merupakan sumber protein nabati yang penting. Biji buncis banyak mengandung vitamin A, B dan C (Sunaryo dan Rismunandar, 1981).

Luas tanam buncis pada tahun 2010 98 ha dengan luas panen 96 ha dengan produksi 496 ton dengan produktivitas mencapai 50,57 ku.ha-1 ${ }^{-1}$ Pada tahun 2011 luas tanam buncis di Hulu Sungai Tengah mencapai 42 ha dengan luas panen 38 ha 
dengan produksi mencapai 267 ton dengan produktivitas mencapai 63,56 ku.ha ${ }^{-1}$. Pada tahun 2013 luas tanam buncis mencapai 42 ha dengan luas panen mencapai 37 ha dengan produksi 216 ton dengan produktivitas mencapai 58,92 ku.ha-1 (Dinas Tanaman Pangan dan Hortikultura HST, 2012).

Tanah podsolik merupakan tanah yang memiliki tingkat kesuburan sedang. Tanahnya berwarna merah atau kekuningkuningan. Tanah podsolik mempunyai karakteristik tekstur yang lempung atau berpasir degan $\mathrm{pH}$ rendah serta memiliki kandungan unsur aluminium dan besi yang tinggi. Karakteristik lain yang dapat ditemui pada tanah podsolik adalah daya simpan unsur hara sangat rendah karena bersifat lempung yang beraktifitas rendah, kejenuhan unsur hara sangat rendah karena bersifat lempung yang beraktifitas rendah, kejenuhan unsur basa seperti $\mathrm{K}, \mathrm{Ca}$, dan $\mathrm{Mg}$ rendah dan hanya terdapat dipermukaan tanah saja, dan penyimpanan air sangat rendah sehingga mudah mengalami kekeringan (Intan, 2011). Meskipun memiliki banyak kekurangan, tanah podsolik dapat ditingkatkan. Perbaikan sifat fisika dapat ditanggulangi dengan perbaikan sifat ketahanan daya penyimpanan air. Sementara perbaikan sifat kimiawinya dapat dilakukan dengan memperbaiki kandungan unsur hara yang ada didalam tanah (Anneahira, 2012). Tanah podsolik yang akan digunakan untuk penelitian memiliki kandungan hara yang beragam. Kandungan C-Organik (\%) 0,317 termasuk sedang, $\mathrm{pH}\left(\mathrm{H}_{2} \mathrm{O}\right) 6,63$ masuk katagori agak masam, $\mathrm{N}$ total $(\%) 0,154$ rendah, $\mathrm{P}$ total $(\mathrm{mg} / 100 \mathrm{~g})$ rendah, $\mathrm{K}$ total $(\mathrm{mg} / 100 \mathrm{~g})$ rendah, $\mathrm{Ca}$ (me/100 g) sedang, besi (Fe) tinggi (Balittra, 2013). Hasil ini menunjukkan tanah dalam kondisi kesuburan yang rendah.

Kelebihan pupuk cair urine sapi adalah mempunyai jumlah kandungan nitrogen, fosfor, kalium dan air lebih banyak jika dibandingkan dengan kotoran sapi padat; mengandung zat perangsang tumbuh yang dapat digunakan sebagai pengatur tumbuh; serta mempunyai bau yang khas urine ternak yang dapat mencegah datangnya berbagai hama tanaman. Selama ini masih jarang penggunakan urine sapi sebagai pupuk padahal urine sapi memiliki prospek yang bagus untuk diolah menjadi pupuk cair karena mengandung unsur-unsur yang sangat dibutuhkan oleh tanaman secara lengkap seperti $\mathrm{N}, \mathrm{P}, \mathrm{K}, \mathrm{Ca}, \mathrm{Mg}$ yang terikat dalam bentuk senyawa organik. Disamping itu penggunaan pupuk cair organik dari urine sapi ini dapat menambah keuntungan para petani, karena mengurangi biaya operasional perawatan tanaman (Naswir, 2013).

Urine sapi yang paling baik untuk diolah menjadi pupuk cair adalah urine sapi murni segar (kurang dari 24 jam) yang belum bercampur dengan cemaran lain yang ada dalam kandang. Dalam pembuatan pupuk urine, setiap $200 \quad \ell$ urine sapi segar membutuhkan bakteri pengurai yang berupa produk EM-4 atau biotani sebanyak 0,5\% dan molases atau larutan gula sebagai energi bakteri sebanyak $1 \ell$ (Sudiro, 2011).

Pada pemberian konsentrasi urine sapi $45 \mathrm{cc} . \ell^{-1}$ memberikan pengaruh nyata pada hasil tanaman kacang-kacangan. Penggunaan Urine sapi berpengaruh nyata terhadap pertumbuhan dan hasil tanaman kacang panjang, semakin tinggi dosis semakin tinggi hasilnya. Dosis 8 ton.ha ${ }^{-1}$ berpengaruh nyata bila dibandingkan dengan kontrol, tetapi tidak berbeda nyata bila dibandingkan dengan dosis 10 ton.ha ${ }^{-1}$ (Pardono, 2009). Tujuan Penelitian ini untuk (i) mengetahui pengaruh pemberian berbagai dosis pupuk urine sapi terhadap pertumbuhan dan hasil tanaman buncis pada lahan podsolik (ii) mendapatkan dosis terbaik dari berbagai macam dosis pupuk urnie sapi terhadap pertumbuhan dan hasil tanaman buncis pada lahan podsolik.

\section{METODE PENELITIAN}

Penelitian ini dilaksanakan di Desa Pantai Hambawang Timur Kecamatan Labuan Amas Selatan Kabupaten Hulu Sungai Tengah dari bulan Juni-Juli 2014, penelitian ini menggunakan Rancangan Acak Kelompok (RAK), dengan 5 perlakuan dan 4 ulangan, sehingga didapatkan 20 satuan percobaan, dan setiap perlakuan ada 4 tanaman. Faktor yang diuji adalah dosis 
pupuk cair urine sapi, yaitu : $\mathrm{t}_{0}=0 \mathrm{cc} \cdot \ell^{-1}$ per petakan, $\mathrm{t}_{1}=35$ cc. $\ell^{-1}$ per petakan, $\mathrm{t}_{2}=45$ cc. $\ell^{-1}$ per petakan, $\mathrm{t}_{3}=55 \mathrm{cc} \cdot \ell^{-1}$ per petakan, $\mathrm{t}_{4}=$ 65 cc. $\ell^{-1}$ per petakan. Pelaksanaan penelitian terdiri dari tahap persiapan, pelaksanaan, pemeliharaan, pemanenan dan pengamatan. Pengamatan dilakukan terhadap panjang tanaman, jumlah polong dan berat polong.

\section{HASIL DAN PEMBAHASAN}

\begin{abstract}
Hasil
Panjang Tanaman

Berdasarkan hasil analisis ragam peubah data yang diamati menunjukkan bahwa pemberian pupuk urine sapi berpengaruh nyata terhadap panjang tanaman buncis umur 15, 25, dan 35 HST. Rata-Rata tinggi tanaman dapat dilihat pada Tabel berikut.
\end{abstract}

Tabel 1. Hasil uji beda rata-rata panjang tanaman buncis

\begin{tabular}{crrr}
\hline \multirow{2}{*}{ Perlakuan } & \multicolumn{3}{c}{ Rata-rata panjang tanaman $(\mathrm{cm})$} \\
\cline { 2 - 4 } & $15 \mathrm{HST}$ & $25 \mathrm{HST}$ & $35 \mathrm{HST}$ \\
\hline $\mathrm{t}_{0}$ & $13,9375^{\mathrm{a}}$ & $56,6250^{\mathrm{a}}$ & $110,3750^{\mathrm{a}}$ \\
$\mathrm{t}_{1}$ & $15,9375^{\mathrm{b}}$ & $105,0625^{\mathrm{b}}$ & $136,0000^{\mathrm{b}}$ \\
$\mathrm{t}_{2}$ & $15,9375^{\mathrm{b}}$ & $109,6250^{\mathrm{b}}$ & $137,6875^{\mathrm{b}}$ \\
$\mathrm{t}_{3}$ & $16,1875^{\mathrm{b}}$ & $127,0625^{\mathrm{b}}$ & $152,4375^{\mathrm{b}}$ \\
$\mathrm{t}_{4}$ & $16,8750^{\mathrm{b}}$ & $127,3750^{\mathrm{b}}$ & $159,6875^{\mathrm{b}}$ \\
\hline
\end{tabular}

Keterangan : Nilai rata-rata yang diikuti huruf yang berbeda menunjukkan perlakuan tersebut berbeda nyata berdasarkan uji DMRT pada taraf nyata $5 \%$

Dari Tabel 1 terlihat bahwa pada umur $15 \mathrm{HST}$, perlakuan $\mathrm{t}_{4}$, menunjukkan rata-rata panjang tanaman terpanjang $16,8750 \mathrm{~cm}$ yang tidak berbeda nyata dengan perlakuan $\mathrm{t}_{1}, \mathrm{t}_{2}$, dan $\mathrm{t}_{3}$ tetapi berbeda nyata dengan perlakuan $t_{0}$. Pada umur 25 hst, perlakuan $\mathrm{t}_{4}$ menunjukkan panjang tanaman terpanjang yaitu $127,3750 \mathrm{~cm}$ yang tidak berbeda nyata dengan perlakuan $t_{1}, t_{2}$, dan $t_{3}$ tetapi berbeda nyata dengan perlakuan $t_{0}$. Pada umur $35 \mathrm{HST}$, perlakuan $\mathrm{t}_{4}$ juga menunjukkan rata-rata panjang tanaman yaitu $159,6875 \mathrm{~cm}$ yang tidak berbeda nyata dengan perlakuan $t_{1}, t_{2}$, dan $t_{3}$ tetapi berbeda nyata dengan perlakuan $t_{0}$.

\section{Jumlah Polong}

Berdasarkan hasil analisis ragam peubah data yang diamati menunjukkan bahwa pemberian pupuk urine sapi berpengaruh nyata terhadap jumlah polong tanaman buncis. Rata-rata jumlah polong tanaman buncis dapat dilihat pada Tabel 2.

Tabel 2. Hasil uji beda rata-rata jumlah polong tanaman buncis

\begin{tabular}{cc}
\hline Perlakuan & Rata-rata jumlah polong pertanaman \\
\hline $\mathrm{t}_{0}$ & $21,5875 \mathrm{a}$ \\
$\mathrm{t}_{1}$ & $22,9375 \mathrm{ab}$ \\
$\mathrm{t}_{2}$ & $23,3125 \mathrm{ab}$ \\
$\mathrm{t}_{3}$ & $24,9375 \mathrm{~b}$ \\
$\mathrm{t}_{4}$ & $25,2500 \mathrm{~b}$ \\
\hline
\end{tabular}

Keterangan : Nilai rata-rata yberdasarkan uji DMRT pada taraf nyata $5 \%$

Dari Tabel 4 terlihat bahwa perlakuan $\mathrm{t}_{4}$ menunjukkan rata-rata jumlah polong terbanyak yaitu 25,25 polong yang tidak berbeda nyata dengan perlakuan $\mathrm{t}_{1}, \mathrm{t}_{2}$, dan $\mathrm{t}_{3}$ tetapi berbeda nyata dengan perlakuan $\mathrm{t}_{0}$.

\section{Berat Polong}


Berdasarkan hasil analisis ragam peubah data yang diamati menunjukkan bahwa pemberian pupuk urine sapi berpengaruh nyata terhadap berat polong tanaman buncis. Rata-rata berat polong tanaman dapat dilihat pada Tabel 3.

Tabel 3. Hasil uji beda rata-rata berat polong tanaman buncis

\begin{tabular}{cc}
\hline Perlakuan & Rata-rata berat polong pertanaman $(\mathrm{g})$ \\
\hline t0 & $24,1425 \mathrm{a}$ \\
t1 & $33,3687 \mathrm{~b}$ \\
t2 & $35,9750 \mathrm{~b}$ \\
t3 & $37,1437 \mathrm{bc}$ \\
t4 & $40,5000 \mathrm{c}$ \\
\hline
\end{tabular}

Keterangan : Nilai rata-rata yang diikuti huruf yang berbeda menunjukkan perlakuan tersebut berbeda nyata berdasarkan uji DMRT pada taraf nyata $5 \%$

Dari Tabel 3 terlihat bahwa perlakuan $\mathrm{t}_{4}$ menunjukkan rata-rata berat polong terberat yaitu 40,50 g yang tidak berbeda nyata dengan $t_{3}$ tetapi berbeda nyata dengan $t_{0}, t_{1}$, dan $t_{2}$. Perlakuan terbaik didapat pada $t_{4}$.

\section{Pembahasan}

Berdasarkan hasil penelitian memperlihatkan perlakuan pemberian dosis pupuk cair urine sapi menunjukan pengaruh nyata pada semua peubah tanaman yang diamati. Hal ini karena pupuk cair urine sapi yang digunakan dalam penelitian ini mengandung unsur-unsur yang lengkap, baik unsur hara makro seperti N, P, K, Ca dan unsur mikro seperti $\mathrm{Fe}, \mathrm{Mn}, \mathrm{Zn}$, Co dan $\mathrm{Cu}$ yang sangat diperlukan dalam pertumbuhan dan perkembangan tanaman.

Hasil analisis tanah menunjukkan bahwa lahan penelitian mengandung $\mathrm{C}$ organik yang rendah yaitu $0,317 \%$ dan kandungan $\mathrm{N}$-total yang rendah yaitu 0,154 $\%$. Dari hasil analisis tanah tersebut maka diketahui penelitian ini memilik $\mathrm{C} / \mathrm{N}$ rasio yang rendah (Balittra, 2013).

Menurut Sutrisno (1989), bahwa dengan pemberian unsur hara dalam jumlah yang cukup akan memberikan pertumbuhan yang normal pada tanaman. Dengan pertumbuhan yang normal maka akan meningkatkan potensi genetik tanaman seperti bentuk, ukuran, dan berat buah yang di hasilkan. Dari hasil uji beda tengah terlihat bahwa hasil terpanjang pada perlakuan $\left(\mathrm{t}_{4}\right)$ dosis $65 \mathrm{cc} . \ell^{-1}$ per petakan yang berbeda nyata terhadap perlakuan lain terutama dengan control ( $\left.\mathrm{t}_{0}\right) \quad 0 \quad \mathrm{cc} . \ell^{-1}$ perpetakan. Diduga bahwa pada saat fase pertumbuhan vegetative tanaman, ketersediaan unsur hara yang terdapat pada pupuk cair urine sapi memenuhi untuk pertumbuhan buncis sehingga unsur-unsur tersebut dapat diserap dengan baik oleh tanaman, khususnya unsur Nitrogen $(\mathrm{N})$ yang banyak terkandung pada pupuk cair urine sapi. Hal ini sesuai dengan pernyataan Lingga dan Marsono (2007) yang menyatakan bahwa peranan utama dari nitrogen adalah untuk merangsang pertumbuhan secara keseluruhan bagian tanaman khususnya batang, cabang dan daun tanaman.

Berdasarkan hasil analisis ragam menunjukkan bahwa pemberian pupuk cair urine sapi berpengaruh nyata terhadap jumlah polong. Dari hasil uji beda nilai tengah terlihat bahwa hasil yang tertinggi pada perlakuan $\left(\mathrm{t}_{4}\right)$ yaitu pada dosis $65{\mathrm{cc} . \ell^{-}}^{-}$ ${ }^{1}$ perpetakan. Hal ini diduga karena pupuk cair urine sapi mampu memberikan ketersediaan unsur hara yang cukup bagi pertumbuhan generatif tanaman.

Fungsi utama unsur hara $\mathrm{N}$ adalah untuk merangsang pertumbuhan tanaman secara keseluruhan pada masa vegetatif, sehingga pupuk yang diberikan bertujuan agar pertumbuhan vegetatif tanaman lebih cepat dan lebih baik. Unsur hara fosfor $(\mathrm{P})$ berfungsi untuk mengedarkan energi keseluruh bagian tanaman, berguna untuk merangsang pertumbuhan dan 
perkembangan akar, khususnya akar tanaman muda. Tanaman yang kekurangan unsur hara P maka daun tanaman akan kuning kemudian rontok dan tanaman menjadi kerdil (Lakitan, 2006).

Adanya pengaruh yang nyata dari pemberian pupuk urine sapi apabila dibandingkan dengan tanpa penggunaan pupuk cair urine sapi $\left(\mathrm{t}_{0}\right)$, diduga karena pengaruh unsur $\mathrm{P}$ dan adanya zat perangsang tumbuh yaitu auksin yang terdapat pada pupuk cair urine sapi. Menurut Lingga dan Marsono (2007), unsur P diperlukan untuk tanaman memperbanyak pertumbuhan generatif (bunga, polong dan buah) sehingga kekurangan unsur $\mathrm{P}$ dapat menyebabkan produksi tanaman menjadi menurun.

Menurut Salisbury dan Ross (1992) auksin dapat memacu kerja sitokinin dalam proses pembelahan dan pembesaran sel, serta auksin juga dapat memacu kerja sitokinin dalam menginduksi enzim-enzim yang berfungsi dalam pembelahan sel terutama pada primordia daun. Sedangkan menurut Lakitan (2006) mekanisme masuknya unsur hara dan zpt dalam sel tanaman melalui proses difusi pada sel tanaman yang dipengaruhi oleh permeabilitas membran sel dan perbedaan potensial air didalam dan diluar sel. Difusi air akan meningkatkan tekanan turgor dalam sel, sehingga air masuk kedalam vakuola yang selanjutnya akan mengatur pertumbuhan sel dan primordia daun.

Berdasarkan dari hasil analisis ragam menunjukkan bahwa pemberian dosis pupuk cair urine sapi berpengaruh nyata terhadap berat polong pertanaman. Hal ini diduga karena pupuk cair urine sapi mampu memberikan unsur hara yang cukup bagi pertumbuhan generatif tanaman. Perlakuan terbaik didapatkan pada dosis $65 \mathrm{cc} . \ell^{-}$ ${ }^{1}$ perpetakan $\left(\mathrm{t}_{4}\right)$ karena ketersediaan unsur hara bagi pertumbuhan generatif tanaman mencapai titik optimal pada dosis tersebut.

Menurut Naswir (2003), fungsi zat perangsang tumbuh auksin pada tanaman antara lain merangsang pertumbuhan dan mempertinggi persentase timbulnya bunga dan buah, partenokarpi yaitu suatu kondisi dimana tanaman berbuah tanpa fertilasi atau penyerbukan, mengurangi gugurnya buah sebelum waktunya, serta mematahkan dominasi pucuk atau apical yaitu suatu kondisi dimana pucuk tanaman atau akar tidak mau berkembang.

Pada perlakuan $\mathrm{t}_{0}$ terlihat beberapa tanaman terserang hama dan penyakit, pada daun terlihat bercak-bercak dan adanya lubang-lubang di polong buncis bekas gigitan ulat. Walaupun tidak sampai merusak keseluruhan tanaman buncis. Hal ini di duga karena perlakuan $t_{0}$ tanaman kekurangan unsur hara $\mathrm{P}$ yang menyebabkan tanaman mudah terserang penyakit. Menurut Makarim (1955) bahwa unsur $P$ berperan dalam mempercepat pembentukan buah, bunga dan biji, memperbaiki kualitas tanaman serta meningkatkan daya tahan terhadap penyakit. Pemupukan daun dengan menggunakan urine sapi yang mengandung N, P, K serta Cayang lebih tinggi dapat meningkatkan ketahanan terhadap hama dan penyakit.

\section{KESIMPULAN}

Perlakuan berbagai dosis pupuk urine sapi berpengaruh nyata terhadap semua peubah yang diamati, yaitu panjang tanaman, jumlah polong dan berat polong tanaman buncis pada lahan podsolik. Dosis $65 \mathrm{cc} . \ell^{-1}$ merupakan dosis terbaik pada pertumbuhan dan hasil tanaman buncis pada lahan podsolik.

\section{DAFTAR PUSTAKA}

Anneahira. 2012. Seputar Tanaman Hortikultura.http://www.anneahira.co $\mathrm{m} /$ tanaman-hortikultura.htm.

Balittra. 2013. Laboratorium Tanah, Tanaman dan Air. Balai Penelitian Pertanian Lahan Rawa (Balittra). Banjarbaru.

Dinas Tanaman Pangan dan Hortikultura. 2012. Data Produksi Sayuran. Dinas Tanaman Pangan dan Hortikultura. HST. 
Intan, P. 2011. Tanah Podsolik. http://putroeintan.blogspot.com

Diakses tanggal 08 Februari 2014.

Lakitan, B. 2006. Dasar-dasar Fisiologi Tumbuhan. Raja Grafindo Persada. Jakarta.

Lingga dan Marsono. 2007. Edisi Revisi. Petunjuk Penggunaan Pupuk. Penebar Swadaya. Jakarta.

Makarim, A. 1955. Silikon Hara Penting Tanaman Padi. http://www.kimialipi.net/indexx. Diakses tanggal 07 September 2014.

Naswir. 2013. Pemanfaatan Urine Sapi Yang Dipermentasi sebagai Nutrisi Tanaman. http://soil.faperta.ugm.ac.id. Diakses tanggal 08 Februari 2014.

Pardono. 2009. Pengaruh Pupuk Organik Air Kencing Sapi dan Pupuk Kandang terhadap Pertumbuhan dan Hasil Kacang Panjang (Vigna Sinensis L.).http://soil.faperta.ugm.ac.id.

Diakses tanggal 8 Februari 2014.

Salisbury, F. B. dan Ross, C. W. 1992. Fisiologi Tumbuhan Jilid 3. Institut Teknologi Bandung. Bandung.

Sunaryo, dan Rismunandar. 1981. Kunci Bercocok tanam Sayur-Sayuran Penting di Indonesia. CV. Sinar Baru. Bandung.

Sutrisno T. 1989. Pemupukan dan Pengelolaan. CV Armico. Bandung. 